\title{
OBITUARIES
}

\section{Mr. S. A. Moseley}

The death occurred on December 5, 1961, of Sydney Alexander Moseley, an author and journalist, who played an enthusiastic part in promoting the initial development of the Baird television system in Great Britain.

$\mathrm{He}$ was born in London in 1888, and joined the staff of the Daily Express in 1910. Later, he edited various newspapers in Egypt, and became the Cairo correspondent of the New York Times and the Paris Daily Mail. In 1914, after a period in the University of London Officers' Training Corps, he became the official correspondent to the Mediterranean Expeditionary Force. After the First World War, Moseley became a newspaper writer on radio both in Britain and in the United States. He was a founder and life member of the Overseas Press Club of America, and founder and first president of the Broadcast Critics' Circle.

It was as a journalist that Moseley first became interested in Baird's early experiments in television and his endeavours to raise money to support these. After witnessing a laboratory demonstration of the transmission of a visual image, he foresaw in this the beginnings of television; and he devoted time and energy to publicizing Baird's work in the Press. Later, he joined the Baird Television Company, and co-operated enthusiastically with the inventor in his struggles to obtain recognition and adequate support.

Sydney Moseley was the announcer on the occasion of the first experimental television broadcast made by the B.B.C. in September 1929, when a letter was read from the President of the Board of Trade, Sir William Graham, and speeches given by Sir Ambrose Fleming and Prof. E. N. da C. Andrade, followed by some entertainment. Moseley was also instrumental in arranging with the B.B.C. and the Post. master-General for the Derby to be televised in May 1931, and a year later a large-screen demonstration of the finish of the Derby was given in a London cinema fifteen miles from the race-course at Epsom.

Many of his experiences and impressions during this pioneer work in television are described by Moseley in some half-dozen books, of which Television Today and Tomorrow (1930) and Broadcasting in My Time (1935) may be mentioned. He also wrote an interesting biography, John Baird, with the subtitle The Romance and Tragedy of the Pioneer of Television.

In addition to music, opera, swimming, tennis and golf, Moseley counted among his recreations "losing money made by writing by speculation on the Stock Exchange".

R. L. Sмith-Rose

\section{Prof. August Žáček}

DR. AUGUST Ž́̆́̌́EK, late professor of experimental physics at the Charles University of Prague, died on October 26, 1961, at the age of seventy-five. $\mathrm{He}$ became director of the Department of Physics of that University in 1922 and acted in that capacity until 1940, when the University was taken over by the Gormans during the occupation of Czechoslovakia and he was deprived of his post. $\mathrm{He}$ was re-instated to his former position at the end of the War, but, for obscure reasons, was forced to retire prematurely after the new régime had been established in Czechoslovakia in 1948. From then on he was not able to make use of the laboratory and library facilities of the University and other scientific organizations, and lived in poverty and isolation, though still keenly interested in physics and trying to continue working.

His main field of research was alternating current, especially of high frequency, where his greatest achievement was the invention of the 'magnetron', a device for generating very short electromagnetic waves, consisting of a cylindrical diode placed in a magnetic field parallel to its axis. This device is now generally used for the determination in teaching laboratories of the specific charge of the electron, and it was, in greatly improved form, extensively used during the Second World War as a generator for radar waves. He also carried out important work on piezo-electric quartz oscillators. During 1921-22 he worked with Siegbahn in Sweden on X-ray spectra, especially on the $L$-series of the newly discovered hafnium.

$\mathrm{He}$ was an excellent and devoted teacher with a very wide experience in teaching experimental physics to students of physics, chemistry, medicine and pharmacy, and he published a number of text-books in the Czech language based on his lecture courses.

Žáček was a person of great charm and wit, with a wide and liberal outlook and the courage to express his opinions freely. The few of his personal friends who are still alive will remember him lovingly and deplore the cruel fate which cut short the working life of a distinguished scholar. R. H. FürTH

\section{Mr. Cedric Dover}

Some men's lives mirror the intellectual movements of their generation. Cedric Dover, who died in London of a heart attack on December 9, 1961, was a writer of many talents. But all of them reflected the movement by which coloured people have asserted their political and cultural dignity.

Born in Calcutta of Eurasian parents, Dover was employed in the Zoological Survey of India and was then sent by Dr. N. Annandale to study zoology at Edinburgh. But after two years he returned to a series of appointments with the Malayan and Indian Governments as entomologist, ostreoculturist and lecturer at the Indian Forest College. At the same time he studied contemporary attempts to develop a scientific study of minority problems and cultivated support for Congress among the Eurasian community.

In 1934 Dover put entomology on one side to concentrate on criticizing the current biological approach to problems of racial mixture. This he did in a scintillating and polished book, Half-Caste (1937), which embodied the results of his wide travels and a review of racial thought against a world perspective. It played an influential part in the subsequent re-evaluation of the nature and consequences of miscegenation.

After demobilization from the Royal Army Medical Corps, Dover spent two years lecturing in the United States before returning to live in London. Though his mind often returned to biological problems, especially to sub-speciation and the taxonomy of 
human variation, his chief interests now lay in the cultural field. He published a series of papers on the racial philosophies of Herder, Ibn Khaldun. Halevi and Antar, and other works, notably his poems Brown Phoenix (1950) and American Negro Art (1960). In these historical writings, as in his sociology and politics, Cedric Dover was continuously a leader of new trains of thought. His scientific training, sparkling prose and wide-ranging sympathy enabled him to do this with distinction. Michael Banton

\section{NEWS and VIEWS}

Atomic Energy Commission (Australia), Lucas Heights Research Establishment: Mr. K. F. Alder

Mr. Keith Frederick Alder has been appointed director of the Lucas Heights Research Establish. ment of the Atomic Energy Commission. He succeeds Dr. G. C. J. Dalton, who died in July (Nature, 191, $1142 ; 1961)$. Mr. Alder, who was previously deputy director, had been acting director for some time. Mr. Alder is a metallurgist with a distinguished career. An increasingly important part of the Commission's programme is research into the properties of materials which might be used in the development of an advanced form of nuclear power reactor. Mr. Alder has played a leading part in this work, and some of the results which are now beginning to emerge are attracting considerable interest in other countries. Mr. Alder was born in Melbourne in 1921 and graduated at the University there in 1942. He went to the Ammunition Factory at Footscray, Victoria, as metallurgist, and then lectured in metallurgy at the Newcastle (New South Wales) Technical College. In 1949 he worked on weapons research for the British Government; this work involved beryllium and plutonium--metals of importance also in nuclear reactors for the generation of electricity. He returned to Australia, and during 1951-53 lectured at Newcastle University College and then at the University of Melbourne. Shortly after the Commission was formed, Mr. Alder joined the staff, and worked with the Australian research team at the Harwell Research Establishment of the United Kingdom Atomic Energy Authority. As head of the Metallurgy Section, he played an important part in the general organization of the staff, equipment and buildings for Lucas Heights.

Econometrics and Social Statistics at Birmingham : Prof. A. A. Walters

Mr. A. A. WALterRs, formerly lecturer in economotries in the University of Birmingham, has been elected professor of econometries and social statistics in that University. Prof. Walters's main teaching interests have been concerned with applied econometrics. One important development at Birmingham has been the integrated teaching of mathematics, economics and statistics. Prof. Walters has introduced courses in applied econometries which have played a central part in this approach. For future teaching development there are two main proposals: the first is to extend the integrated method of teaching in econometric techniques to business studies; the second is the broadening of degree courses in engineering by the inclusion of special courses in mathematical economics and management econometrics for engineers. In theoretical research, Prof. Walters has been concerned with interpreting economic theory when tho basic variables aro stochastic in character. In empirical research, Prof. Walters has concentrated on the statistical verification of economic theory, and particularly on the use of engineering data for testing hypotheses. He is at present engaged on three pieces of empirical research: on investment relations; on the measurement of cost and production functions; and on economic develop. ment. Collaboration on research with departments in applied science is likely to be even closer, as new ways are discovered for using technological data in the social sciences. The Department of Econometrics and Social Statistics will continue its work on development problems, production functions, stochastic processes, and problems of measuring social phenomena.

\section{U.S. National Bureau of Standards :}

Mr. B. L. Page

Mr. Benjamin L. Page has retired from the post of chief of the Length Section at the National Bureau of Standards, U.S. Department of Commerce, after forty-three years at the Bureau. Mr. Page is well known for the very precise length measurements of line standards he has made. Mr. Page has been in charge of the laboratory that has custody of a platinum-iridium meter bar known as 'Prototype Meter No. 27', which was the national standard of length for seventy years. He was responsible for comparing it with the various secondary line standards of length and long-gauge blocks which are measured in terms of the wave-length of light. In 1960 the meter bar was replaced as the national standard of length by a wave-length of krypton-86 light. Mr. Page, together with other members of the Bureau staff, participated in the measurement of the meter bar in terms of the wave-length of krypton light, the first such direct determination ever per. formed.

Mr. T. R. Young

THEODORE R. Young has been appointed to succeed Mr. Page. Mr. Young will direct a programme which makes accurate and rapid length measurements of the standards which Federal and State agencies, manufacturers and scientists send to the Bureau for calibration. 'The Bureau compares various standards of length (including line standards and precision gauge blocks) in order to ensure unity of results of line, end and wave-length standards. Mr. Young joined the staff of the National Bureau of Standards as a physicist in the Optical Instruments Section in 1949. $\mathrm{He}$ developed large-aperture interferometers and applied them to testing large lens systems and the homogeneity of glass. In 1954 he was assigned to the superprecision gauge block programme in the Enginoering Metrology Section. This project, originally sponsored in part by a group of private industrial manufacturers, has as its goal the development of stable gauge blocks and to measure their lengths accurately to one part in ten million. Mr. Young became chief of this project in 1959 . 